\title{
Correction to: Online medication purchasing during the Covid-19 pandemic: a pilot study from the United Arab Emirates
}

\author{
Ammar Abdulrahman Jairoun', Sabaa Saleh Al-Hemyari ${ }^{2}$, Naseem Mohammed Abdulla ${ }^{1}$, Faris El-Dahiyat ${ }^{3^{*}}$ (i), \\ Maimona Jairoun ${ }^{4}$, Saleh Karamah AL-Tamimi ${ }^{5}$ and Zaheer-Ud-Din Babar ${ }^{6}$
}

\section{Correction to: J of Pharm Policy and Pract (2021) 14:38 https://doi.org/10.1186/s40545-021-00320-z}

Following the publication of the original article [1], the authors notified us of a few errors, reflected below:

1. Title:

- Originally published: "Online medication purchasing during the Covid-19 pandemic: potential risks to patient safety and the urgent need to develop more rigorous controls for purchasing online medications, a pilot study from the United Arab Emirates".

- Corrected: "Online medication purchasing during the Covid-19 pandemic: A pilot study from the United Arab Emirates".

2. Reference 9

- Original (incomplete): "Bukhari N, Rasheed H, Nayyer B, Babar ZUD (2020) Pharmacists at the "frontline beating the COVID-19 pandemic".

- Updated: "Bukhari, N., Rasheed, H., Nayyer, B. et al. Pharmacists at the frontline beating the
COVID-19 pandemic. J of Pharm Policy and Pract 13, 8 (2020). https://doi.org/10.1186/s40545-02000210-w".

The original article has been corrected.
Author details

${ }^{1}$ Health and Safety Department, Dubai Municipality, Dubai, UAE. ${ }^{2}$ Department of Pharmacy, Ministry of Health and Prevention, Dubai, UAE. ${ }^{3}$ College of Pharmacy, Al Ain University, Al Ain, UAE. ${ }^{4}$ College of Pharmacy and Health Sciences, Ajman University, Ajman, UAE. ${ }^{5}$ Faculty of Pharmacy, Aden University, Aden, Yemen. ${ }^{6}$ Department of Pharmacy, School of Applied Sciences, University of Huddersfield, Huddersfield HD1 3DH, West Yorkshire, UK.

Published online: 11 May 2021

\section{Reference}

1. Jairoun AA, Al-Hemyari SS, Abdulla NM, El-Dahiyat F, Jairoun M, AL-Tamimi SK, Babar Z. . Online medication purchasing during the Covid-19 pandemic: a pilot study from the United Arab Emirates es. J of Pharm Policy and Pract. 2021;2021(14):38. https://doi.org/10.1186/s40545-021-00320-z

\section{Publisher's Note}

Springer Nature remains neutral with regard to jurisdictional claims in published maps and institutional affiliations. is not included in the article's Creative Commons licence and your intended use is not permitted by statutory regulation or exceeds the permitted use, you will need to obtain permission directly from the copyright holder. To view a copy of this licence, visit http://creativecommons.org/licenses/by/4.0/. The Creative Commons Public Domain Dedication waiver (http://creativecommons.org/publicdomain/zero/1.0/) applies to the data made available in this article, unless otherwise stated in a credit line to the data. 